\title{
Research streams in corporate social responsibility literature: a bibliometric analysis
}

\author{
Ilka Marie Frerichs ${ }^{1}$ (D) Thorsten Teichert $^{2}$ (D)
}

Received: 27 January 2021 / Accepted: 20 August 2021 / Published online: 9 September 2021

(c) The Author(s) 2021

\begin{abstract}
Corporate social responsibility (CSR) research is heterogeneous and still fragmented. In its interdisciplinary setting, researchers focus on different CSR aspects, secondary concepts and themes. The lack of a unifying paradigm indicates that the CSR literature should be summarized and classified. This study's systematic overview of CSR research provides such a classification. Previous conceptualizations of CSR research mapped the literature from individual authors' perspective, rendering different and partly inconsistent classifications. Using bibliometric methods, this paper offers an objective overview. We analyze the references of $1902 \mathrm{CSR}$ journal articles by bibliometric techniques as (co-)citation, core/periphery, factor, and network analyses. By doing that, we provide an overview of the CSR research core, identify different research streams, describe their main publications' topics and recent developments, and make suggestions to inspire future research in and across research streams. Our results show the increased relevance of formerly niche research streams, such as employee-oriented CSR research, or research on consumer skepticism. Among others, process-oriented and micro-level research, critical approaches, and mergers between themes from various research fields offer a wide scope for further research.
\end{abstract}

Keywords Corporate social responsibility $\cdot$ CSR conceptualization $\cdot$ Research streams $\cdot$ Bibliometrics $\cdot$ Co-citation analysis

\section{JEL Classification M140}

Thorsten Teichert

thorsten.teichert@uni-hamburg.de

Ilka Marie Frerichs

ilka.frerichs@hsu-hh.de

1 Chair of Human Resource Management, Helmut Schmidt University, University of the Federal Armed Forces Hamburg, Holstenhofweg 85, 22043 Hamburg, Germany

2 Chair of Marketing and Innovation, University of Hamburg, Von-Melle-Park 5, 20146 Hamburg, Germany 


\section{Introduction}

Corporate social responsibility (CSR) issues have become a core part of corporate management practice (Crane et al. 2015), with multinational companies such as Coca-Cola, Pfizer, Disney and Wells Fargo releasing annual CSR reports that outline their efforts and achievements. At the same time, scientific interest in CSR and its literature's breadth and depth continues to grow and is turning out to be quite widespread (e.g. Crane et al. 2018). However, the heterogeneous and fragmented research field (Aguinis and Glavas 2012) still lacks a unifying theoretical lens, shared construct clarity, and applied methodology (Gond et al. 2020; Mitnick 2019; Wood and Logsdon 2019).

The variety in concept definitions, approaches, and perspectives is already evident from a nomological perspective: The 'corporate' component stresses CSR's business-centered perspective, the term 'social' addresses its societal perspective, and 'responsibility' emphasizes its ethical side. The diverse CSR research field can be grouped into instrumental, descriptive, and normative research (Mitnick 2019; Wood and Logsdon 2019). Contesting perspectives such as "instrumental/economic CSR" and "injunctive/social CSR" (Mitnick et al. 2021, p. 625) are based on contrasting paradigms. Depending on the applied research paradigm, this results in different implications regarding CSR motives, stakeholders to be favored and aspired outcomes. For example, taking a business-centric perspective, social activities are viewed as more desirable if shareholders react positively to them (Wang et al. 2016), but can be problematic from an ethical point of view.

Fragmentation and broadening the research field have led researchers away from the objective of identifying a unifying paradigm (Gond et al. 2020). Recent research studies and reviews cover single CSR topics, specific theoretical backgrounds or secondary concepts and subfields (Gond et al. 2020; Ji et al. 2021). Examples are reviews dedicated to CSR communication (e.g. Crane and Glozer 2016; Verk et al. 2021), CSR knowledge in communication literature (Ji et al. 2021), political CSR (e.g. Frynas and Stephens 2015) and its micro-foundations (e.g. Gond et al. 2017). Recent research also links CSR to related concepts such as sustainability (e.g. Ketprapakorn 2019), and this is sometimes distinguished from CSR (e.g. Bansal and Song 2017) but is also used as a synonym (e.g. Cantele and Zardini 2018).

Due to this heterogeneity, researchers characterize the literature as a low-paradigm research field (Gond et al. 2020; Mitnick 2019; Wood and Logsdon 2019) and as "essentially contested" (Mitnick et al. 2021, p. 624). They view CSR as an umbrella term (Frynas and Yamahaki 2016; Scherer and Palazzo 2007) and accept the heterogeneity and controversies. We also value research heterogeneity, but argue that there should be attempts to better integrate the various research streams ( $\mathrm{Ji}$ et al. 2021) to facilitate dialogue and cross-fertilization (Mitnick et al. 2021).

Against this background, we strive to enrich the CSR research field by a broad, systematic review that provides a neutral perspective on the discipline as well as its development over time. Thereby this study complements narrative reviews that are inherently more restricted in their scope as well as more subjective in nature. We aim to identify the CSR literature's overall research structure and connections 
across subfields (Ji et al. 2021). We describe research streams based on bibliometric criteria that are not clearly discernable (Ma et al. 2012), making the "invisible college network" (Ji et al. 2021) visible. Going beyond qualitative literature reviews, we employ quantitative empirical bibliometric methods to ensure a more objective review process (Kuntner and Teichert 2016; Zupic and Čater 2015). By conducting citation, co-citation, core/periphery, factor, and network analyses, we contribute to the development of the research field from a methodological point of view. We also analyze how the research streams evolved over time and identify recent trends. Finally, we make suggestions that could inspire future research in and across CSR research streams.

\section{Categorizations of CSR literature}

Publications that describe the field more holistically have identified different perspectives on CSR. Table 1 provides an overview of these diverse categories. Looking at the categorizations, it becomes evident that there is a lack of a unifying paradigm (Gond et al. 2020), as the research field is mapped in different ways that are based on different underlying views on CSR. The heterogeneity starts with an interpretation of what should be included in CSR research. For example, Dahlsrud (2008) extends the three CSR components of corporate, social, and responsible to five dimensions, namely the environmental, social, economic, stakeholder, and voluntariness dimensions.

The CSR categories differ largely by the categorization bases used to classify CSR research. They are grouped according to organizations' social roles (Klonoski 1991), key approaches (Windsor 2006), theoretical groups (e.g. Garriga and Melé 2004; Secchi 2007), theories and concepts (Frynas and Yamahaki 2016; Ji et al. 2021) or paradigmatic frameworks (Gond and Matten 2007; Scherer and Palazzo 2007). Even classifications applying the same categorization basis come to different conclusions. For example, Garriga and Melé (2004) as well as Secchi (2007) categorize CSR research by grouping theories behind CSR research. While the former research team divides CSR research into four groups that refer to instrumental, political, integrative, or ethical theories (Garriga and Melé 2004), Secchi (2007) differentiates between CSR research based on utilitarian, managerial, and relational theories.

Other inconsistencies result from allocating research streams differently into the various categories. This is exemplified by different classifications of the stakeholder theory: The early work of Garriga and Melé (2004) categorizes stakeholder management as an integrative theory, which separates this CSR research stream from works related to corporate citizenship and social contract theory (the latter being part of their political group). In contrast, Secchi (2007) assigns stakeholder theory to the relational theories along with corporate global citizenship and social contract theory. Furthermore, the granularity and contents of identified categories differ. Whereas Gond and Matten (2007) distinguish four paradigms in the CSR research field based on Burrell and Morgan (1979), Scherer and Palazzo (2007) summarize positivist and 


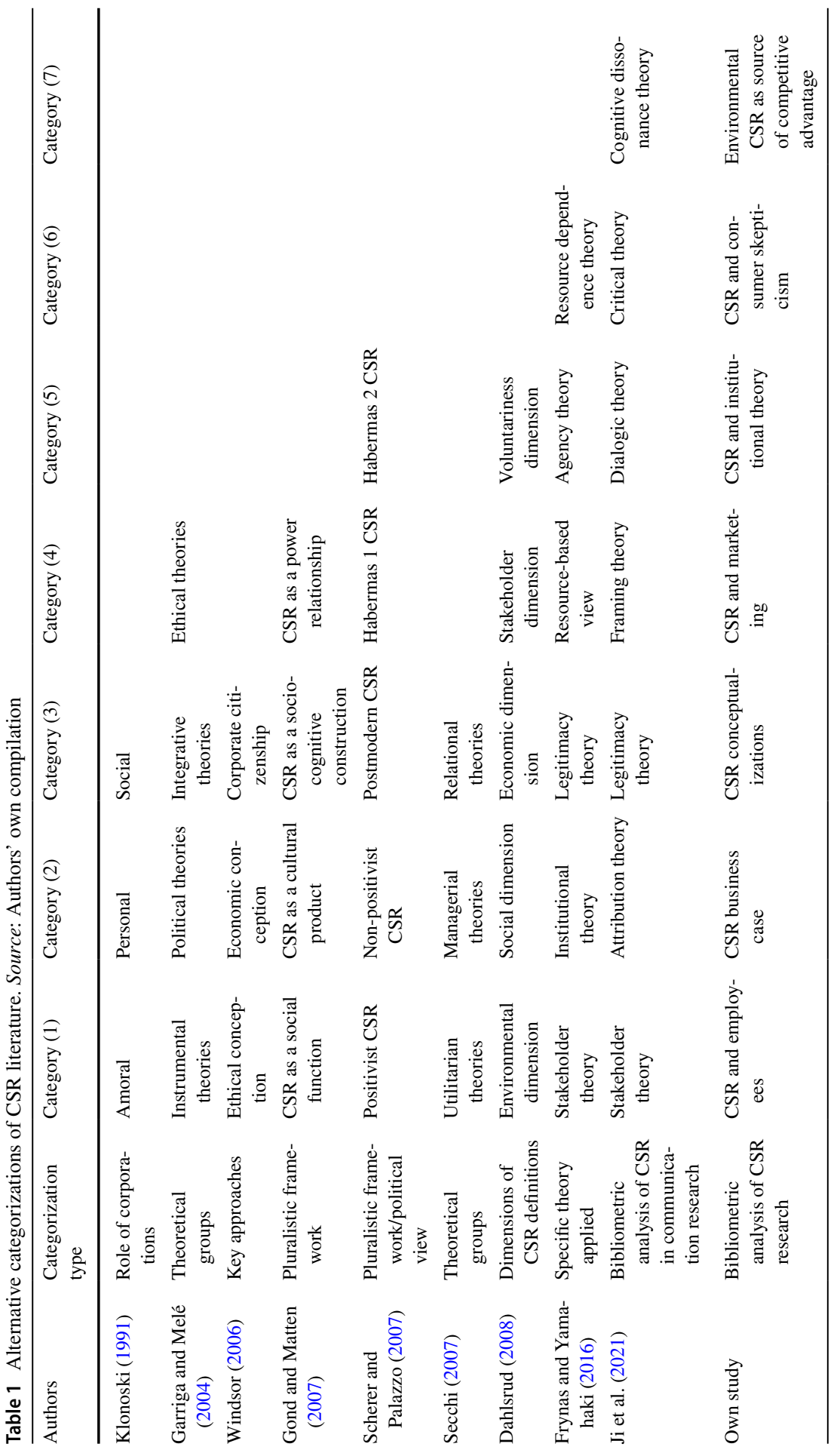


post-positivist schools of thought and propose a politicized CSR conceptualization based on Habermasian philosophy.

Previous categorizations often did not base on existing publications, but on subjectively desirable research streams, such as the yet unexplored category 'Habermas 2 CSR' (Scherer and Palazzo 2007). The exceptions are previous bibliometric, publication, and citation analyses (De Bakker et al. 2005; Lockett et al. 2006), which predominantly used only counting methods from the multitude of quantitative bibliometric methods and therefore require a methodological extension. Previous bibliometric studies that used sophisticated quantitative methods do not refer to individual research streams of CSR literature, but to the entire business ethics literature (Calabretta et al. 2011; Ma 2009; Ma et al. 2012). Some of these studies focus on concepts and theories in a specific subdiscipline, such as CSR research in communication literature ( $\mathrm{Ji}$ et al. 2021), while we analyze all research streams of the CSR literature. This is particularly important, as we aim to describe the entire CSR research structure across these subfields ( $\mathrm{Ji}$ et al. 2021), attempting to uncover the invisible network ( $\mathrm{Ji}$ et al. 2021; Ma et al. 2012). Targeting the entire CSR research field enables us to provide insights about the actual roles that specific research streams play in the overall CSR research and to reveal additional research streams that may deserve more attention.

\section{Method}

\subsection{Data generation}

Our analysis included several research steps. First, we generated data by searching for CSR-related articles in the Social Sciences Citation Index (SSCI). This database is most commonly and frequently used for bibliometric analyses in management and organizational studies (Zupic and Čater 2015) and recommended for its comprehensiveness, especially for our subject field (e.g. Ma et al. 2012). We had access to the index since 1994, therefore we searched for publications that appeared between 1994 and 2020. We chose 'corporate social responsibility' as a search term and added 'AND organization*' to establish the connection to organizational research, and looked for these terms in titles, abstracts, and/or author keywords. Without this organizational focus, for example, topics from technology science (e.g. Mills and De Paoli 2018) would have been included. By using truncation, we included terms from an employee perspective, such as organizational justice, organizational citizenship behavior (Rupp et al. 2013), or organizational commitment (Brammer et al. 2007).

To ensure a high scientific quality, we focused on double-blind reviewed articles written in English, as is common practice in bibliometric studies (e.g. Wörfel 2019). Our data included 1902 articles citing 146,220 references. While we restricted the search to reviewed articles, their references included numerous other types of publications such as books (e.g. Bowen 1953; Freeman 1984) or Friedman's important New York Times Magazine article published in 1970, as we will show in the results of the co-citation analysis. 
We analyzed the citations as well as the co-citations of cited references to derive information about the CSR literature's intellectual structure (White and Griffith 1981). To overcome the 'long tail end' of the citation frequencies' distribution, we first limited our analysis of referenced documents to the most prominent articles. We selected references cited at least 30 times, which resulted in 291 key references used for co-citation analysis. Later, we also analyzed all citing articles up to 2020. This combination of analyses allowed us to overcome the inherent problem of co-citation analysis that recent papers have a lower chance of being co-cited and to link current research to identified long-term research streams and to reveal their current trends.

\subsection{Data analysis}

Following a descriptive analysis of citing papers, our bibliometric study bases on a multistage analysis of the cited documents as their intellectual basis. A co-citation analysis quantifies how often publications are cited together (Pilkington and Teichert 2006). While a high number of citations are associated with a publication's importance in the research field, a high number of co-citations of two publications indicate that they share similar ideas and belong to an overarching research stream (Small 1977). Co-citations can therefore identify key publications as well as distinct streams. We build a co-citation matrix of cited references and analyze them in multiple steps. First, we analyze the entire co-citation network, differentiating core publications from publications in the periphery. We then describe the relative contribution of individual publications by statistical measures on a single node level. Research streams are been identified by means of factor analysis and their temporal development is analyzed.

To conduct a core/periphery analysis based on the co-citation matrix, we used the software UCINET 6.665 (Borgatti et al. 2002). The core forms a cohesive structure with publications that are central to the topic and strongly related to each other. Publications in the periphery are only loosely connected and they relate to specific research themes (Borgatti and Everett 2000). Furthermore, we calculated statistical measures to indicate the research core's overarching structure, called degree centrality, eigenvector centrality, and betweenness centrality. We used Freeman's degree to measure the total number of a publication's co-citations in the database (Freeman 1978). The eigenvector centrality represents an extension of the degree centrality by considering the importance of articles to which a publication is related (Bihari and Pandia 2015). The eigenvector score, which also underlies Google's page ranking (Langville and Meyer 2006), reflects various publications' centrality in the entire research field better than unweighted measures do. Finally, the betweenness centrality reveals the extent to which a publication acts as a 'bridge' between otherwise unconnected publications in a network.

Factor analyses were conducted with SPSS to identify different research streams in the core as well as in the periphery (Kuntner and Teichert 2016). Statistical measures infer single publications' relevance in each research stream. The factor loadings indicate the publications' fit to the research streams' context, while the factor scores reversely indicate how much the publication influences the respective research 
stream (Teichert and Shehu 2010). Finally, all citing articles up to 2020 are linked to the research streams based on their citation patterns. The number of citations an individual research stream receives per year (publication year of the citing articles) is set in relation to the total number of citations (Kuntner and Teichert 2016). This final analysis reveals the evolution of the research streams and helps identify recent trends in CSR research.

\section{Findings}

\subsection{Descriptive overview of the most prominent citing articles}

Table 2 provides a descriptive overview of our initial database of 1902 citing articles. It lists the top 10 journals as well as the top 10 most prominent articles (measured by their received number of citations).

While the 1902 articles were published in over 400 journals, most appear in a few key journals. Nearly half of all identified articles were published in the top 10

Table 2 Most frequent journals and most cited publications of citing articles. Source: Authors' own compilation

\begin{tabular}{lc}
\hline 10 most frequent journals & Record count \\
\hline Journal of Business Ethics & 382 \\
Sustainability & 120 \\
Corporate Social Responsibility and Environmental Management & 99 \\
Business Society & 56 \\
Journal of Cleaner Production & 52 \\
Business Ethics: A European Review & 45 \\
Public Relations Review & 39 \\
Journal of Business Research & 35 \\
Management Decision & 26 \\
Business Strategy and the Environment & 22 \\
\hline 10 most cited articles & Times cited \\
\hline Sen and Bhattacharya (2001) & 1984 \\
Campbell (2007) & 1810 \\
Aguilera et al. (2007) & 1349 \\
Van Marrewijk (2003) & 952 \\
Surroca et al. (2010) & 800 \\
Maignan and Ferrel (2004) & 734 \\
Lichtenstein et al. (2004) & 713 \\
Brammer et al. (2007) & 521 \\
Doh and Guay (2006) & 520 \\
Burke and Logsdon (1996) & 492 \\
\hline
\end{tabular}

${ }^{a}$ Data retrieved on 12.05.2021. Current values may increase due to additional citations 
journals. The Journal of Business Ethics published about 20\% of the identified cited articles and is therefore of special importance in CSR research. More focused journals, such as Sustainability, Corporate Social Responsibility and Environmental Management, Journal of Cleaner Production, and Business Strategy and Environment indicate the relevance of the environmental CSR dimension (e.g. Babiak and Trendafilova 2011). The Journal of Business Research and Public Relations Review are included in the top 10 journals and highlight the relevance of aspects such as CSR communication (e.g. Abitbol and Lee 2017).

A view of the 10 most often referenced publications provides a first glimpse of important topics in CSR research. These articles include overviews on CSR drivers (Aguilera et al. 2007) and on CSR's link to sustainability (Van Marrewijk 2003). Other articles focus on different stakeholder groups such as customers (e.g. Lichtenstein et al. 2004; Sen and Bhattacharya 2001) or employees (e.g. Brammer et al. 2007), as well as on marketing (e.g. Maignan and Ferrell 2004). Links between CSR, financial performance, or strategic benefits are also analyzed (e.g. Burke and Logsdon 1996; Surroca et al. 2010), highlighting the relevance of strategic approaches to CSR. Institutional CSR research is been investigated by a study of CSR in different institutional contexts (Doh and Guay 2006) as well as by an exploration of institutional CSR drivers (Campbell 2007). In sum, various topics are been identified by looking at top journals and single top publications. Yet it is unclear whether these topics are representative of all CSR research. The following analyses therefore broaden the scope of investigation and assess schools of thought in the research field by a complementary co-citation analysis of cited references.

\subsection{Core articles}

A core/periphery analysis identified the shared basis of cited references in the research field. It separated 43 publications in the core from 248 publications in the periphery. First, we zoomed into the analysis of core works to give an overview of the foundation of CSR research. Table 3 lists these key publications and provides a summary of derived statistics, showing their degree centrality, eigenvector centrality, and betweenness centrality.

Unsurprisingly, foundational conceptual models, meta-analyses and reviews of CSR assume focal positions in this list of core publications. They are cited most often, rendering the highest degree centrality as well as eigenvector centrality values. The publications by McWilliams and Siegel (2001) and Orlitzky et al. (2003) are cited 5773 and 5254 times respectively, and therefore stand out in terms of centrality. The latter study is a meta-analysis of 52 studies showing many ties to articles throughout the core CSR literature network. The stakeholder framework by Clarkson (1995) received fewer citations. A comparably low eigenvector centrality (ranked 25) characterizes the article, indicating that it had a more focused impact.

The table's findings also illustrate the importance of the CSR business case in the core literature. Articles that analyze the relation between CSR or rather corporate social performance and corporate financial performance (e.g. Margolis and Walsh 
Table 3 Core cited articles in the CSR discourse. Source: Authors' own compilation

\begin{tabular}{|c|c|c|c|c|c|c|c|}
\hline \multirow{2}{*}{$\begin{array}{l}\text { Publications }^{\mathrm{a}} \\
\text { McWilliams and Siegel (2001) }\end{array}$} & \multicolumn{2}{|c|}{$\begin{array}{l}\text { Degree centrality } \\
\text { (rank) }\end{array}$} & \multicolumn{2}{|c|}{$\begin{array}{l}\text { Eigenvector cen- } \\
\text { trality (rank) }\end{array}$} & \multicolumn{2}{|c|}{$\begin{array}{l}\text { Betweenness central- } \\
\text { ity (rank) }\end{array}$} & \multirow{2}{*}{$\begin{array}{l}\text { Factor } \\
2\end{array}$} \\
\hline & 5773 & (1) & $100 \%$ & (1) & 69.55 & (1) & \\
\hline Carroll (1979) & 5633 & (2) & $99 \%$ & (2) & 69.55 & (1) & 3 \\
\hline Orlitzky et al. (2003) & 5254 & (3) & $89 \%$ & (4) & 69.55 & (1) & 2 \\
\hline Freeman (1984) & 5084 & (4) & $91 \%$ & (3) & 69.55 & (1) & 3 \\
\hline Aguinis and Glavas (2012) & 5049 & $(5)$ & $79 \%$ & (6) & 69.55 & (1) & 1 \\
\hline Aguilera et al. (2007) & 4894 & (6) & $81 \%$ & (5) & 69.55 & (1) & 5 \\
\hline Waddock and Graves (1997) & 4136 & (7) & $69 \%$ & (7) & 68.48 & (9) & 2 \\
\hline Turban and Greening (1997) & 4058 & (8) & $66 \%$ & (8) & 67.76 & (13) & 4 \\
\hline Margolis and Walsh (2003) & 3855 & (9) & $65 \%$ & (9) & 66.51 & (15) & 2 \\
\hline Matten and Moon (2008) & 3676 & $(10)$ & $60 \%$ & (11) & 67.82 & (11) & 5 \\
\hline Porter and Kramer (2006) & 3597 & (11) & $61 \%$ & (10) & 67.79 & $(12)$ & $\mathrm{N} / \mathrm{A}^{\mathrm{b}}$ \\
\hline Sen and Bhattacharya (2001) & 3576 & (12) & $57 \%$ & (14) & 65.26 & (18) & 4 \\
\hline Brammer et al. (2007) & 3421 & (13) & $55 \%$ & (16) & 48.89 & $(54)$ & 1 \\
\hline Campbell (2007) & 3402 & (14) & $56 \%$ & (15) & 67.99 & $(10)$ & 5 \\
\hline Fornell and Larcker (1981) & 3381 & (15) & $53 \%$ & (19) & 52.20 & $(42)$ & 4 \\
\hline Donaldson and Preston (1995) & 3367 & (16) & $58 \%$ & (12) & 65.29 & $(17)$ & 2 \\
\hline Carroll (1991) & 3263 & (17) & $57 \%$ & (13) & 69.55 & (1) & 3 \\
\hline Ashforth and Mael (1989) & 3212 & (18) & $51 \%$ & $(20)$ & 49.71 & $(50)$ & 1 \\
\hline Wood (1991) & 3206 & (19) & $55 \%$ & (17) & 65.01 & (19) & 3 \\
\hline Podsakoff et al. (2003) & 3028 & $(20)$ & $47 \%$ & (24) & 59.68 & $(27)$ & 1 \\
\hline Greening and Turban (2000) & 3021 & (21) & $49 \%$ & $(22)$ & 56.15 & $(34)$ & 1 \\
\hline Rupp et al. (2006) & 2993 & $(22)$ & $47 \%$ & (23) & 47.85 & $(56)$ & 1 \\
\hline Friedman (1970) & 2982 & $(23)$ & $55 \%$ & (18) & 64.30 & (20) & $N / A^{b}$ \\
\hline Carroll (1999) & 2956 & (24) & $50 \%$ & (21) & 69.55 & (1) & 3 \\
\hline Clarkson (1995) & 2755 & $(25)$ & $47 \%$ & (25) & 67.03 & (14) & 3 \\
\hline Kim et al. (2010) & 2732 & $(26)$ & $42 \%$ & $(27)$ & 42.81 & $(80)$ & 1 \\
\hline Turker (2009b) & 2689 & (27) & $43 \%$ & (26) & 38.02 & (99) & 1 \\
\hline Dutton et al. (1994) & 2621 & $(28)$ & $41 \%$ & $(30)$ & 46.31 & $(60)$ & 1 \\
\hline Peterson (2004) & 2569 & (29) & $41 \%$ & (29) & 45.17 & $(66)$ & 1 \\
\hline Jones (2010) & 2543 & $(30)$ & $38 \%$ & (35) & 40.22 & $(88)$ & 1 \\
\hline McWilliams and Siegel (2000) & 2499 & $(31)$ & $42 \%$ & (28) & 57.88 & $(31)$ & 2 \\
\hline Luo and Bhattacharya (2006) & 2487 & $(32)$ & $40 \%$ & $(32)$ & 59.77 & $(26)$ & 4 \\
\hline DiMaggio and Powell (1983) & 2446 & (33) & $37 \%$ & (36) & 48.53 & $(55)$ & 5 \\
\hline Mitchell et al. (1997) & 2422 & (34) & $41 \%$ & $(31)$ & 58.92 & $(28)$ & 1 \\
\hline McWilliams et al. (2006) & 2369 & (35) & $39 \%$ & (33) & 63.31 & $(22)$ & 2 \\
\hline Rupp et al. (2013) & 2356 & (36) & $35 \%$ & (39) & 29.28 & $(140)$ & 1 \\
\hline Brown and Dacin (1997) & 2268 & (37) & $36 \%$ & (37) & 53.99 & $(37)$ & 4 \\
\hline Barnett (2007) & 2261 & (38) & $35 \%$ & $(38)$ & 65.73 & (16) & 2 \\
\hline Garriga and Melé (2004) & 2261 & (38) & $38 \%$ & (34) & 58.12 & (29) & 3 \\
\hline Suchman (1995) & 2193 & $(40)$ & $33 \%$ & $(41)$ & 49.02 & $(53)$ & 1 \\
\hline Turker (2009a) & 2135 & $(41)$ & $34 \%$ & $(40)$ & 53.02 & $(40)$ & 1 \\
\hline Carmeli et al. (2007) & 2067 & (43) & $31 \%$ & (46) & 40.70 & $(87)$ & 1 \\
\hline Maignan et al. (1999) & 2027 & (44) & $32 \%$ & (43) & 52.14 & (43) & 1 \\
\hline
\end{tabular}


Table 3 (continued)

${ }^{a}$ Only the 43 core articles are displayed, whereas the ranking is based on the entire 291 articles

${ }^{b}$ N/A: missing values result from articles that could not be allocated to a specific factor

2003; Orlitzky et al. 2003; Waddock and Graves 1997) illustrate this importance. The core contains overviews of definitions (Carroll 1999), theories (e.g. Garriga and Melé 2004), and drivers of socially responsible behavior (e.g. Aguilera et al. 2007; Aguinis and Glavas 2012; Campbell 2007). It also includes fundamental corporate social performance models (Carroll 1979, 1991; Wood 1991). According to these models, corporations do not only have economic and legal responsibilities, but are also responsible in an ethical and discretionary sense. As shown by the most relevant citing articles, the descriptive statistics of the core references confirm the relevance of stakeholder theory in CSR research (e.g. Donaldson and Preston 1995; Freeman 1984). Unsurprisingly, the Freeman (1984) book on stakeholder management is among the publications with the highest centrality values. The core also includes a few fundamental publications on institutional CSR perspectives (e.g. Campbell 2007; DiMaggio and Powell 1983; Matten and Moon 2008). We therefore confirm the descriptive results of the citing articles, as well as earlier findings that demonstrate the importance of stakeholder and institutional approaches in CSR theorization (Frynas and Yamahaki 2016).

Over time, scientists have concluded that it would be fruitful to analyze how CSR affects specific stakeholder groups (Peterson 2004). Our findings also reflect this. The core includes many CSR publications connected to employees (e.g. Brammer et al. 2007; Carmeli et al. 2007; Kim et al. 2010; Rupp et al. 2006, 2013) and a few articles associated with consumers (e.g. Brown and Dacin 1997; Luo and Bhattacharya 2006). It should be noted that, compared to general fundamental CSR conceptualizations (e.g. Carroll 1979, 1991) and reviews (e.g. Carroll 1999), more specific and recent studies on CSR and employees (e.g. Rupp et al. 2013) exhibit low values of betweenness centrality. Therefore they do not act as a 'bridge' between otherwise unconnected articles.

\subsection{Research streams}

The single articles' descriptive statistics provided a first impression of the CSR research. In another step, we executed factor analyses to investigate the underlying patterns of heterogeneity and to gain insights about different research streams. A factor analysis of publications of the periphery complemented one of core publications, allowing a cross-validation of the findings. In the core, we identified five factors that explain $55.75 \%$ of the variance in the co-citation patterns after eliminating two outlier publications based on low communality values. As expected, the factor analysis of the periphery showed a higher heterogeneity, with several articles excluded due to low communality values and seven factors explaining $42.35 \%$ of the variance. A content analysis confirmed that the periphery's topics relate to the core's five research streams. These were jointly named 'CSR and employees,' the 'CSR 
business case,' 'CSR conceptualizations,' 'CSR and marketing,' and 'CSR and institutional theory.' Two further research streams in the periphery, 'CSR and consumer skepticism' and 'environmental CSR as source of competitive advantage,' do not appear in the core. To provide an overview of all research streams, Table 4 presents the top five most representative and influential publications in each research stream.

The research stream with the highest explained variance covers the topic 'CSR and employees,' highlighting the prominence of this stakeholder perspective in CSR research. The publication of Brammer et al. (2007), also among the top citing articles, is recognized as the most representative article $(\mathrm{FL}=0.88)$ as well as the most influential one $(\mathrm{FS}=1.97)$ in this factor. In this and related articles, the authors use social identity theory as an approach to investigate the perceived CSR influence on employees' organizational commitment (Brammer et al. 2007; Kim et al. 2010; Turker 2009b). Another important aspect covered in this research is the combination of employee-oriented CSR and organizational justice (Rupp et al. 2006, 2013). To summarize, this research stream addresses the outcomes of CSR practices related to employees, which include CSR's influence on concepts like organizational identification (e.g. Jones 2010; Kim et al. 2010) or organizational citizenship behavior (e.g. Rupp et al. 2013). Articles in the periphery also address CSR's micro-foundation in combining employees' perceived CSR judgments. This includes CSR's influence on commitment (e.g. Farooq et al. 2014; Glavas and Kelley 2014), organizational identification (e.g. De Roeck et al. 2014), organizational justice (Rupp and Mallory 2015), job satisfaction (Glavas and Kelley 2014), or CSR and job performance (Vlachos et al. 2014). More interpretative qualitative studies are needed for a better understanding of employees' views on CSR. It appears that this research stream has paid limited attention to employees' influence on CSR implementation.

The second research stream deals with the 'CSR business case.' McWilliams and Siegel's (2001) theory of the firm perspective and Donaldson and Preston's (1995) publication on stakeholder theory provide important theoretical underpinnings for this research. Owing to inconsistent findings on the relationship between corporate social and financial performance, many researchers have analyzed this relationship (e.g. McWilliams and Siegel 2000; Waddock and Graves 1997). Meta-analyses mainly find a positive link (e.g. Orlitzky et al. 2003). Specific empirical works locate in the courses' periphery: Hillman and Keim (2001) as well as Berman et al. (1999) analyzed the influence of concepts like stakeholder management and social issue participation on shareholder value. Other influential articles investigated the economic benefits of CSR activities from a risk management perspective (Godfrey et al. 2009). To summarize, this research stream's core provides the theoretical basis, whereas its periphery comprises empirical studies on the link between social performance and financial performance measures (e.g. Barnett and Salomon 2006; Griffin and Mahon 1997). To look more deeply and from a new perspective at the effects of CSR, this research stream would benefit by process studies and alternative research approaches.

The third research stream, 'CSR conceptualizations,' covers conceptual research on the role of business in society. The two most representative publications written by Carroll $(1979,1991)$ describe the different CSR dimensions by conceptual models such as the CSR pyramid (Carroll 1991). In such frameworks, researchers 


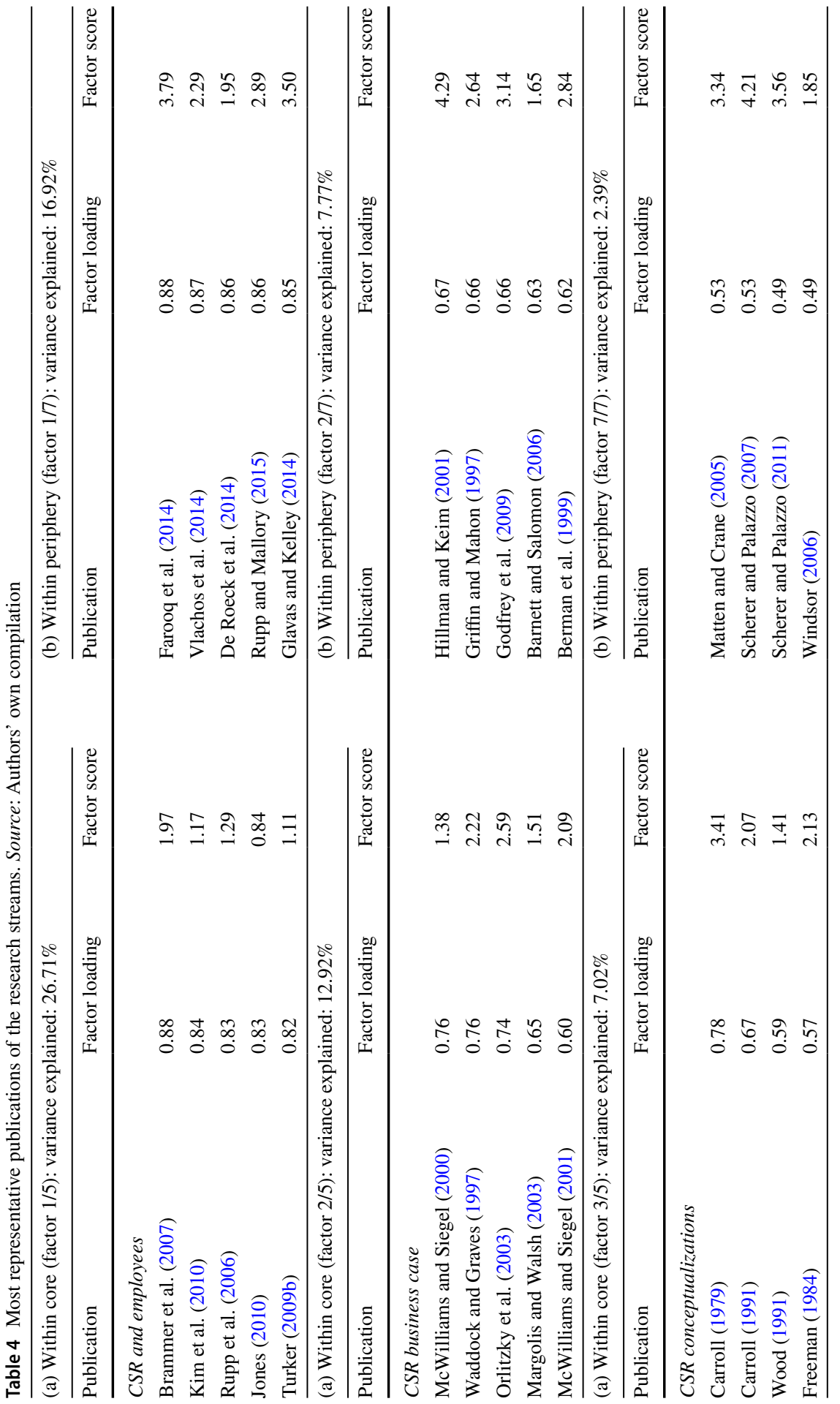









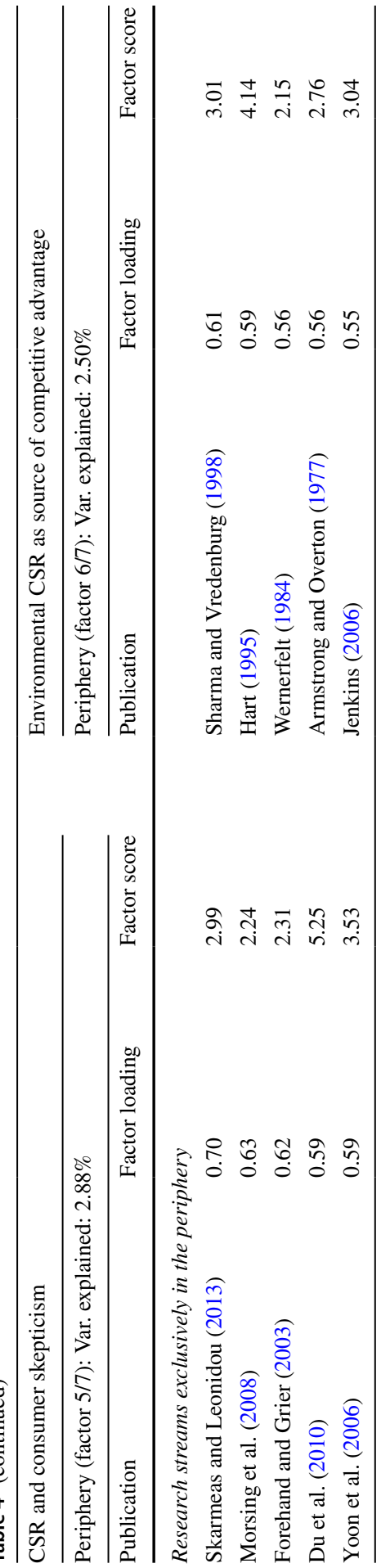


summarized and refined corporations' different responsibilities and define the corporate social performance concept (Carroll 1979, 1991; Wood 1991). The research stream's core includes reviews of CSR definitions (Carroll 1999) and a classification of diverse theories in CSR research (Garriga and Melé 2004). The research stream in the periphery contains publications on the political role organizations play (Scherer and Palazzo 2007, 2011), according to which corporations are active in administering citizenship rights (Matten and Crane 2005). Altogether, works in this discourse highlight the contemporary importance of political theories for CSR research, as with "Habermas's theory of democracy" (Scherer and Palazzo 2007, p. 1096). Publications on political CSR in this research stream are however mainly theory-driven and conceptual (e.g. Scherer and Palazzo 2007, 2011). Relatively recent political CSR conceptualizations therefore offer much potential for empirical research.

The fourth research stream refers to 'CSR and marketing.' It contains empirical articles that quantitatively investigate market responses and the conditions for successful CSR initiatives (Sen and Bhattacharya 2001). Highly influential and representative articles use quantitative methods to investigate concepts like customers' product evaluations (Brown and Dacin 1997), their product purchase intentions and company evaluations (Sen and Bhattacharya 2001), customer satisfaction, and their influence on firms' market value (Luo and Bhattacharya 2006). Publications in the periphery further investigate moderating and mediating effects by zooming into concepts such as customer-corporate identification (Bhattacharya and Sen 2003; Lichtenstein et al. 2004) or trust in explaining how CSR initiatives influence consumer reactions (Morgan and Hunt 1994; Vlachos et al. 2009). Further research investigates consumers' assessment of corporates' motives for practicing CSR (Sen et al. 2006; Vlachos et al. 2009). The findings highlight the positive effects of valuedriven reasons for implementing CSR in marketing campaigns (Vlachos et al. 2009). This topic is predominantly investigated from an uncritical perspective, assuming a positive relationship between CSR initiatives and customer reactions. Critical analyses might enrich this research stream by providing new perspectives.

The fifth research stream deals with 'CSR and institutional theory.' The most representative $(\mathrm{FL}=0.71)$ article analyzes why and how CSR practices vary between the USA and Europe, highlighting the need for corporations to adapt to environmental changes (Matten and Moon 2008). Whereas Campbell (2007) focuses on institutional drivers to behave in a socially responsible way, Aguilera et al. (2007) show multi-level factors that put pressure on organizations to implement CSR practices. Reflections on institutional isomorphic processes (DiMaggio and Powell 1983) serve as a theoretical framework of this debate.

The periphery also contains basic research publications on institutional processes, for example to gain legitimacy (Meyer and Rowan 1977; Oliver 1991; Scott 1995). Organizations often face incompatible institutional logics. How they respond to contradictory institutional demands is one thematic aspect addressed in the periphery (e.g. Greenwood et al. 2011). Specifically, researchers examine the management of complexity in multinational corporations and their impacts on organizational legitimacy (e.g. Kostova and Zaheer 1999). Critical perspectives also enrich this research stream, such as the criticism that multinationals increasingly practice strategic forms 
of CSR at the expense of a more social and stakeholder-oriented understanding of CSR (Bondy et al. 2012). Apart from Asian exceptions (Chapple and Moon 2005), the focus is on developed economies, for example comparisons between the USA and Europe (e.g. Doh and Guay 2006; Matten and Moon 2008).

In the periphery, we identified two more research streams, one of which describes 'CSR and consumer skepticism.' Due to corporate misconduct, many consumers have become skeptical of whether CSR initiatives are sincere (Skarmeas and Leonidou 2013). The highly representative and influential articles show that CSR skepticism is determined by consumers' attribution of companies' motives for practicing CSR (e.g. Forehand and Grier 2003; Yoon et al. 2006). Doubting altruism, many consumers recognize opportunistic motives which they then evaluate negatively (Skarmeas and Leonidou 2013). Consequently, researchers highlight the importance of communication strategies that organizations use to mitigate negative consequences (e.g. Du et al. 2010; Morsing et al. 2008). Studies mainly base on attribution theory (Jones and Davis 1965; Kelley 1973). From a paradigmatic perspective, they are predominantly functionalist, with a focus on effectiveness (e.g. Yoon et al. 2006). In the future, alternative theories such as critical management studies might enrich this perspective.

We also identified a research stream called 'environmental CSR as a source of competitive advantage' in the periphery. Researchers validate relations, such as between environmental CSR, resources and capabilities, and firms' competitive benefits and performances (e.g. Russo and Fouts 1997; Sharma and Vredenburg 1998). To substantiate these links, they use the resource-based view (Barney 1991; Wernerfelt 1984) and the natural-resource-based view (Hart 1995) as their theoretical foundation. Interpreting CSR aspects from a resource perspective is especially important for small and medium-sized enterprises, as they should not treat CSR initiatives solely as costly external effects (Jenkins 2006). Future research might add dynamic and network perspectives to investigate how competitive advantages are been created through CSR initiatives.

\subsection{Development of research streams over time}

Next, we show how the discussion along the different research streams developed over the last 15 years. While the results in the previous section base on cited references, the following analysis bases on the citing articles assigned to the relevant research streams. The citing articles' greater actuality (compared to the cited articles) allowed us to show current trends in the research streams' development. Figure 1 visualizes the research streams' evolution in the core.

Analogously, Fig. 2 shows the trends of the research streams in the periphery. The figures reveal highly dynamic patterns in the evolution of CSR literature. As expected, there are bigger changes in the periphery than in the core.

Research works on 'CSR and employees' gained prominence and are currently by far the most cited publications. This is in line with previous calls for more microlevel CSR research (Aguinis and Glavas 2012; Frynas and Yamahaki 2016), which appears to have stimulated the increase (Gond et al. 2020). It also indicates a shift 


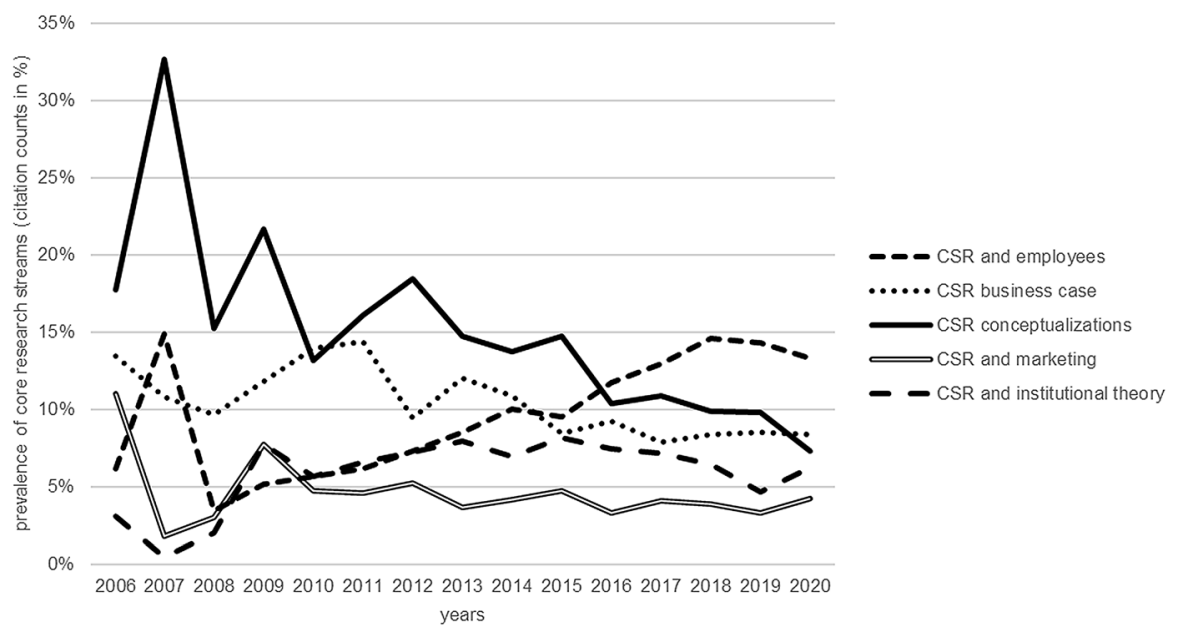

Fig. 1 Prevalence of core CSR research streams from 2006 to 2020. Source: Authors' own illustration

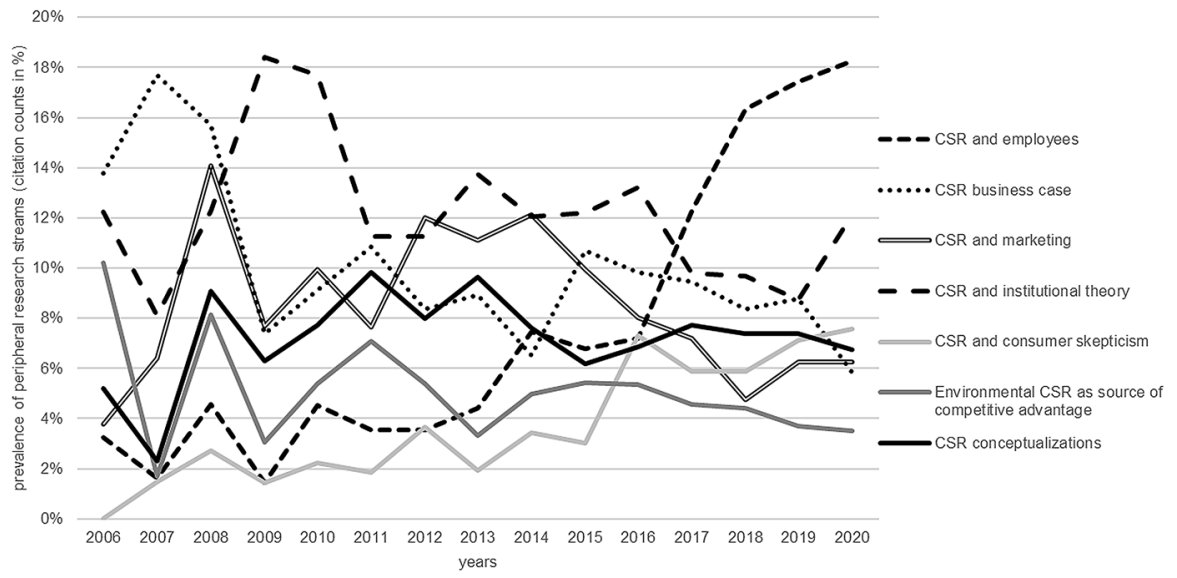

Fig. 2 Prevalence of CSR research streams in the periphery from 2006 to 2020. Source: Authors' own illustration

away from a business point of perspective on CSR to a broader, stakeholder-oriented perspective in CSR research.

References to the 'CSR business case' in research are particularly declining, especially in the periphery. Until 2008, CSR business case research was the most cited research stream in the periphery, but this prevalence decreased significantly in 2009. In the core, CSR business case literature almost always remains the second most referenced research stream until 2014 and again in 2020. Even so, this research stream lost prevalence while employee-oriented CSR research gained importance.

The research stream 'CSR conceptualizations' shows a similar declining trend over the entire period, hinting to a phase of saturation in derived conceptual 
underpinnings. Until 2015, 'CSR conceptualizations' was the core's most referenced research stream. In 2016, references to employee-oriented CSR publications overtook CSR conceptualizations. However, the evolution of political CSR conceptualizations in the periphery differs: Citations of this political subdiscourse increased significantly in 2008. Further peaks occurred in 2011 and 2013 after the release of novel political CSR publications (Scherer and Palazzo 2007, 2011). Thereafter, its importance decreased. Notably, empirical political CSR research might again revitalize the discourse.

Another stream of declining relevance is 'CSR and marketing.' Starting in 2010, this stream became the least often referenced stream out of the five core research streams. In the periphery, marketing-oriented CSR research was more prevalent, peaking in 2008 and for a short period in between 2012 and 2014. Even it decreased afterwards, it has a higher prevalence in 2020 compared to 2006. Nevertheless, we can conclude that the broader discourse on the 'CSR business case' as well as the specific discourse on 'CSR and marketing' became less important over time, deemphasizing the corporate or business view in the CSR discourse.

The number of core publication citations on 'CSR and institutional theory' increased from 2007 to 2009. However, it plays only a moderate role in the CSR research core over time. In contrast, institutional CSR research has high prevalence in the periphery. Although these citations also decreased after 2010, the research stream almost always remained the most important until 2016.

Publications on 'CSR and consumer skepticism' in the periphery gained momentum, especially from 2016 to 2020. Due to rising corporate misconduct (Skarmeas and Leonidou 2013), research on consumer skepticism increasingly replaced the mainstream discourse on positive consumer reactions to CSR initiatives. The growing trend let us assume that this research stream might become more central in the entire research field.

In contrast, the interest in the research stream 'environmental CSR as a source of competitive advantage' has declined. Since 2016, this research stream has received the lowest number of citations of all research streams in the periphery. A reason might be that important publications root back to the 1990s (e.g. Hart 1995; Sharma and Vredenburg 1998) such that a state of saturation was achieved. The discourse might regain attention in the future, considering the widespread diffusion of new consumer movements that link consumer skepticism with environmental aspects and climate change.

\section{Discussion and conclusion}

This paper provides an in-depth analysis of the research streams in the CSR literature. It offers guidance on the CSR literature to new scientists and inspiration for future research to experienced ones. Previous categorizations have led to divergent classifications of CSR research based on researchers' perspective. Our study provides a more objective overview of current CSR research streams by using sophisticated quantitative bibliometric methods (Kuntner and Teichert 2016). One objective was to make the invisible CSR knowledge network visible (Ji et al. 2021; Ma et al. 
2012). The analyses reveal five research streams constituting the core of the research field as well as its periphery. These research streams are 'CSR and employees,' the 'CSR business case,' 'CSR conceptualizations,' 'CSR and marketing,' and 'CSR and institutional theory.' In the periphery we find two more research streams dealing with 'CSR and consumer skepticism' and 'environmental CSR as source of competitive advantage.'

A further aim was to show how the research streams evolved over time. We identified a high degree of dynamics. The research streams on 'CSR and employees,' and 'CSR and consumer skepticism' increased most over time. Comparing 2006 with 2020, the research stream 'CSR and institutional theory' also increased in the core. In the periphery, the latter research stream shows an increasing trend only from 2019 to 2020. Political CSR research also increased in the periphery, when comparing 2006 with 2020. In contrast, the relevance of 'CSR conceptualizations' decreased in the core, just as the core research stream 'CSR and marketing'. The importance of the research streams on the 'CSR business case,' and 'environmental CSR as a source of competitive advantage' also declined. Generally, our results show an overall decreasing significance of business-centered CSR research.

To summarize, Table 5 gives an overview of the different main foci and main methodologies of each research stream. According to our last research objective, it also provides inspirations for future research.

Although the employee-oriented research streams are already prominent, we found major gaps that can inspire future research. The most cited studies examine the positive link of perceived CSR on desirable attitudes and work behavior. However, in the context of corporate misconduct (Lee et al. 2018), it would be interesting to study irresponsible corporate behavior, its impact on employees, and organizational strategies to prevent such misconduct. While there are initial studies (e.g. Lee et al. 2013), this focus area has not yet established itself as a school of thought in CSR research and calls for further research.

In addition, instead of just focusing on how CSR influences employees, future research should also investigate how employees can influence the implementation of CSR practices. While this perspective has been taken sporadically (Bolton et al. 2011), it has not yet established itself as part of the employee-related research streams. A strategy-as-practice approach (Whittington 1996) might be used for such an investigation. Other fruitful sample theories might be the sensemaking theory (Weick et al. 2005) or a critical tension-centered approach (e.g. Trethewey and Ashcraft 2004) for analyzing how employees make sense of CSR and how they derive meaningfulness of work (Aguinis and Glavas 2019; Mitra and Buzzanell 2017). In general, future research should pay more attention to the role of policies in the implementation of CSR practices. Method-wise, qualitative research methods would also enrich employee-related CSR research as most extant studies are quantitative with a one-sided view of the impact of perceived CSR practices on employees (e.g. Brammer et al. 2007).

Research on the 'CSR business case' can be also enriched by using a strategyas-practice approach (Whittington 1996). Khan's (2018) process-oriented study, based on sensemaking theory (Weick et al. 2005), might guide future research investigating the link between CSR strategy formulation and implementation, firm 







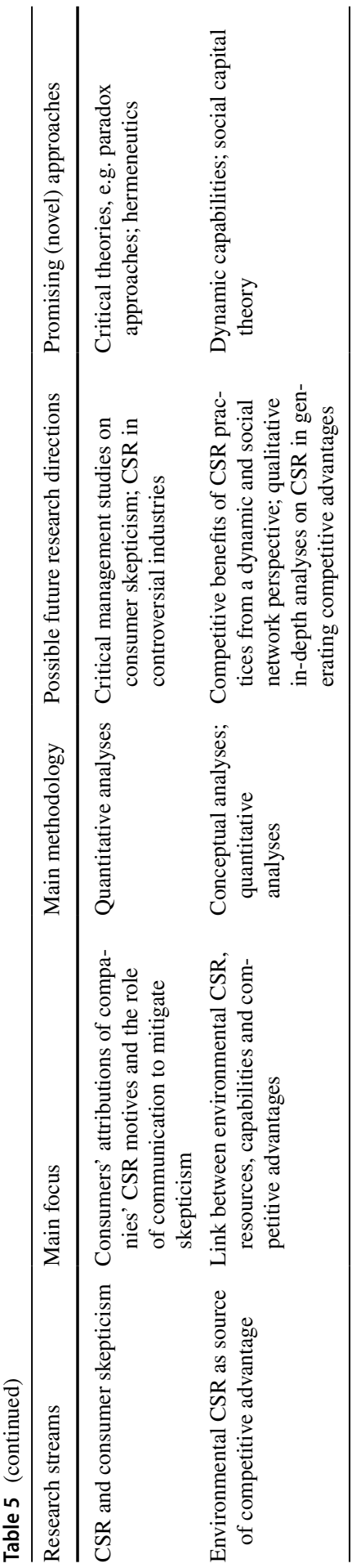


performance, and reputation with a focus on managers' cognitions. Additionally, in contrast to functionalist approaches that deny potential tensions between the ethical and the business case for CSR, more critical studies might focus on the trade-offs between social and economic goals. Paradox approaches would be suitable for this purpose. This is addressed by Hoffmann (2018), who shows how paradoxes of CSR are constituted or denied in research discourses. Contingency approaches might also enrich future CSR business case research that go beyond the convergence model to challenge the perfect alignment between ethical behavior and economic rewards. One such example is the recent published pluralism model by Lynn (2021), which abandons the search for a universal relationship between ethics and economics to instead focus on the situated social mechanisms to foster ethical actions.

The core research stream 'CSR conceptualizations' could benefit from conceptualizations of political CSR, that we find increasingly in the periphery. Publications on the political role of organizations are often conceptual (Scherer and Palazzo 2007, 2011), even in the citing articles (e.g. Wickert 2016). Consequently, the CSR discourse would benefit from empirical investigations of the postulated relationships, such as between responsible leadership styles based on upper echelon theory and the micro-foundations of political CSR (Maak et al. 2016), or between firmlevel determinants and their influence of pursuing political actions in emerging contexts (Shirodkar et al. 2018). Until now, the resource dependence theory (Pfeffer and Salancik 1978) has been under researched in studies on political CSR and might be fruitful for future empirical research (Shirodkar et al. 2018).

The CSR marketing research could be enriched by more critical analyses of the link between perceived CSR and consumer responses. One example might be the influence of corporate greenwashing on consumers (e.g. De Jong et al. 2018). Thus, the marketing discourse may gain from insights of the rising research stream on 'CSR and consumer skepticism.' Method-wise, critical discourse analyses might be useful to unveil the ideological functioning of CSR marketing practices, such as cause-related marketing campaigns, which can be uncovered as strategy to avert ethical corporate criticism and to consolidate business profits (Brei and Böhm 2014).

Our bibliometric analysis confirmed the relevance of institutional theory in CSR research (e.g. Frynas and Yamahaki 2016). Among the cited articles of this discourse, we hardly find any empirical studies of CSR in special institutional contexts, such as in developing, emerging, transitional or post-colonial countries. While we find some works among the more recent citing articles (e.g. Munro et al. 2018), they still rely on mainstream institutional approaches. In the future, critical theories such as post-colonial approaches, for example applied by Jammulamadaka (2020), or power relations approaches might enrich research on CSR issues in such special contexts (Blowfield and Frynas 2005). Method-wise, institutional ethnography could be used as a research practice for such investigations (e.g. Campbell and Kim 2018).

The current trends highlight the growing relevance of psychological CSR (Ji et al. 2021). Attribution theory (Jones and Davis 1965; Kelley 1973) is particularly referenced in the growing research stream on 'CSR and consumer skepticism' (Ji et al. 2021). These studies are predominantly quantitative (e.g. Skarmeas and Leonidou 2013) and paradigmatic functionalist by focusing on organizational benefits due to effective communication (e.g. Du et al. 2010; Yoon et al. 2006). 
Mainstream management researchers focus on communication strategies that companies use extrinsically to convince that CSR practices are mainly driven by intrinsic motives (Hoffmann 2018). Alternative perspectives could further enhance these insights by stressing the communicative constitution of a paradox of conflictual, intermingled and dynamic extrinsic and intrinsic CSR motives (Hoffmann 2018). This research stream might also benefit from inspecting controversial industries that are particularly vulnerable to skepticism about CSR initiatives (Aqueveque et al. 2018). Future critical studies might use qualitative websites and documentary analyses as well as hermeneutics to examine how corporations of such industries communicate about their CSR practices to protect and favor their interests (Hessari and Petticrew 2018; Petticrew et al. 2018).

In the future, 'environmental CSR as a source of competitive advantage' could be analyzed from a more dynamic perspective and with focus on social network relations. For instance, Zhao et al. (2019) consider the mediating effects of dynamic capabilities and social capital on the relation between CSR and competitive advantages In future research, qualitative in-depth studies might enrich this discourse such as Adamik and Nowicki's (2019) study on CSR problems and paradoxes of co-creation in generating competitive advantages.

The examples above provide inspirations for future research directions within each research stream. Future research might as well profit from integrating research across research streams. One possible promising research route may be merging employee-oriented CSR research with studies on consumer skepticism to advance research on employee skepticism (Chaudhary and Akhouri 2018). An integration between employee-oriented studies with political CSR research would also be promising to explore the micro-foundations of organizations' (new) political role (Maak et al. 2016).

Our study has limitations. It bases on peer-reviewed journal articles listed in the SSCI. Other databases such as Scopus or EBSCO Business Source Premier could have extended our initial database of citing articles. However, the analysis of cited references - and therefore the co-citation analysis-goes above and beyond this dataset. Search terms were rather broad and the inclusion of other wordings or terms for individual CSR dimensions could have led to more divergent findings. However, 1,902 citing articles including their references already constitute a database that is large enough to distinguish current schools of thought, identify trends, and infer future research needs.

An inherent problem of bibliometric methods is that recent papers have a smaller chance of being co-citated in other works. However, by also analyzing not only (co-)citations but their citing articles as well, we were able to identify research streams and to link them to their current developments. Our contribution highlights the pillars of CSR research, current literature trends, and inspires future research. We particularly hope to stimulate further cross-sectional research to combine the essence of individual research streams.

Funding Open Access funding enabled and organized by Projekt DEAL. 
Availability of data and materials On request.

\section{Declaration}

Conflict of interest The authors declare that there is no conflict of interests.

Open Access This article is licensed under a Creative Commons Attribution 4.0 International License, which permits use, sharing, adaptation, distribution and reproduction in any medium or format, as long as you give appropriate credit to the original author(s) and the source, provide a link to the Creative Commons licence, and indicate if changes were made. The images or other third party material in this article are included in the article's Creative Commons licence, unless indicated otherwise in a credit line to the material. If material is not included in the article's Creative Commons licence and your intended use is not permitted by statutory regulation or exceeds the permitted use, you will need to obtain permission directly from the copyright holder. To view a copy of this licence, visit http://creativecommons.org/licen ses/by/4.0/.

\section{References}

Abitbol A, Lee SY (2017) Messages on CSR-dedicated facebook pages: what works and what doesn't. Public Relat Rev 43(4):796-808. https://doi.org/10.1016/j.pubrev.2017.05.002

Adamik A, Nowicki M (2019) Pathologies and paradoxes of co-creation: a contribution to the discussion about corporate social responsibility in building a competitive advantage in the age of industry 4.0. Sustainability 11(18):4954. https://doi.org/10.3390/su11184954

Aguilera RV, Rupp DE, Williams CA, Ganapathi J (2007) Putting the S back in corporate social responsibility: a multilevel theory of social change in organizations. Acad Manag Rev 32(3):836-863. https://doi.org/10.5465/amr.2007.25275678

Aguinis H, Glavas A (2012) What we know and don't know about corporate social responsibility: a review and research agenda. J Manag 38(4):932-968. https://doi.org/10.1177/0149206311436079

Aguinis H, Glavas A (2019) On corporate social responsibility, sensemaking, and the search for meaningfulness through work. J Manag 45(3):1057-1086. https://doi.org/10.1177/0149206317691575

Aqueveque C, Rodrigo P, Duran IJ (2018) Be bad but (still) look good: can controversial industries enhance corporate reputation through CSR initiatives? Bus Ethics Eur Rev 27(3):222-237. https:// doi.org/10.1111/beer.12183

Armstrong JS, Overton TS (1977) Estimating nonresponse bias in mail surveys. J Mark Res 14(3):396402. https://doi.org/10.1177/002224377701400320

Ashforth BE, Mael F (1989) Social identity theory and the organization. Acad Manag Rev 14(1):20-39. https://doi.org/10.5465/amr.1989.4278999

Babiak K, Trendafilova S (2011) CSR and environmental responsibility: motives and pressures to adopt green management practices. Corp Soc Responsib Environ Manag 18(1):11-24. https://doi.org/10. 1002/csr.229

Bansal P, Song HC (2017) Similar but not the same: differentiating corporate sustainability from corporate responsibility. Acad Manag Ann 11(1):105-149. https://doi.org/10.5465/annals.2015.0095

Barnett ML (2007) Stakeholder influence capacity and the variability of financial returns to corporate social responsibility. Acad Manag Rev 32(3):794-816. https://doi.org/10.5465/amr.2007.25275520

Barnett ML, Salomon RM (2006) Beyond dichotomy: the curvilinear relationship between social responsibility and financial performance. Strateg Manag J 27(11):1101-1122. https://doi.org/10.1002/ smj.557

Barney J (1991) Firm resources and sustained competitive advantage. J Manag 17(1):99-120. https://doi. org/10.1177/014920639101700108

Berman SL, Wicks AC, Kotha S, Jones TM (1999) Does stakeholder orientation matter? The relationship between stakeholder management models and firm financial performance. Acad Manag J 42(5):488-506. https://doi.org/10.5465/256972 
Bhattacharya CB, Sen S (2003) Consumer-company identification: a framework for understanding consumers' relationships with companies. J Mark 67(2):76-88. https://doi.org/10.1509/jmkg.67.2.76. 18609

Bihari A, Pandia MK (2015) Eigenvector centrality and its application in research professionals' relationship network. In: 2015 International conference on futuristic trends on computational analysis and knowledge management (ABLAZE). IEEE, pp 510-514. https://doi.org/10.1109/ABLAZE.2015. 7154915

Blowfield M, Frynas JG (2005) Setting new agendas: critical perspectives on corporate social responsibility in the developing world. Int Affairs 81(3):499-513. https://doi.org/10.1111/j.1468-2346. 2005.00465.x

Bolton SC, Kim RCH, O'Gorman KD (2011) Corporate social responsibility as a dynamic internal organizational process: a case study. J Bus Ethics 101(1):61-74. https://doi.org/10.1007/ s10551-010-0709-5

Bondy K, Moon J, Matten D (2012) An institution of corporate social responsibility (CSR) in multinational corporations (MNCs): form and implications. J Bus Ethics 111(2):281-299. https://doi. org/10.1007/s10551-012-1208-7

Borgatti SP, Everett MG (2000) Models of core/periphery structures. Soc Netw 21(4):375-395. https:// doi.org/10.1016/S0378-8733(99)00019-2

Borgatti SP, Everett MG, Freeman LC (2002) Ucinet for Windows: software for social network analysis. Analytic Technologies, Harvard

Bowen HR (1953) Social responsibilities of the businessman. Harper \& Row, New York

Brammer S, Millington A, Rayton B (2007) The contribution of corporate social responsibility to organizational commitment. Int J Hum Resour Manag 18(10):1701-1719. https://doi.org/10.1080/09585 190701570866

Brei V, Böhm S (2014) '1L=10L for Africa': corporate social responsibility and the transformation of bottled water into a 'consumer activist' commodity. Discourse Soc 25(1):3-31. https://doi.org/10. $1177 / 0957926513503536$

Brown TJ, Dacin PA (1997) The company and the product: corporate associations and consumer product responses. J Mark 61(1):68-84. https://doi.org/10.1177/002224299706100106

Burke L, Logsdon JM (1996) How corporate social responsibility pays off. Long Range Plan 29(4):495502. https://doi.org/10.1016/0024-6301(96)00041-6

Burrell G, Morgan G (1979) Social paradigms and organizational analysis: elements of the sociology of corporate life. Heinemann, London

Calabretta G, Durisin B, Ogliengo M (2011) Uncovering the intellectual structure of research in business ethics: a journey through the history, the classics, and the pillars of journal of business ethics. $\mathrm{J}$ Bus Ethics 104(4):499-524. https://doi.org/10.1007/s10551-011-0924-8

Campbell JL (2007) Why would corporations behave in socially responsible ways? An institutional theory of corporate social responsibility. Acad Manag Rev 32(3):946-967. https://doi.org/10.5465/ amr.2007.25275684

Campbell ML, Kim E (2018) The (missing) subjects of research on gender and global governance: toward inquiry into the ruling relations of development. Bus Ethics Eur Rev 27(4):350-360. https://doi. org/10.1111/beer.12189

Cantele S, Zardini A (2018) Is sustainability a competitive advantage for small businesses? An empirical analysis of possible mediators in the sustainability-financial performance relationship. J Clean Prod 182:166-176. https://doi.org/10.1016/j.jclepro.2018.02.016

Carmeli A, Gilat G, Waldman DA (2007) The role of perceived organizational performance in organizational identification, adjustment and job performance. J Manag Stud 44(6):972-992. https://doi. org/10.1111/j.1467-6486.2007.00691.x

Carroll AB (1979) A three-dimensional conceptual model of corporate performance. Acad Manag Rev 4(4):497-505. https://doi.org/10.5465/amr.1979.4498296

Carroll AB (1991) The pyramid of corporate social responsibility: toward the moral management of organizational stakeholders. Bus Horizons 34(4):39-48. https://doi.org/10.1016/0007-6813(91) 90005-G

Carroll AB (1999) Corporate social responsibility: evolution of definitional construct. Bus Soc 38(3):269-295. https://doi.org/10.1177/000765039903800303

Chapple W, Moon J (2005) Corporate social responsibility (CSR) in Asia: a seven-country study of CSR web site reporting. Bus Soc 44(4):415-441. https://doi.org/10.1177/0007650305281658 
Chaudhary R, Akhouri A (2018) Linking corporate social responsibility attributions and creativity: modeling work engagement as a mediator. J Clean Prod 190:809-821. https://doi.org/10.1016/j.jclepro. 2018.04.187

Clarkson ME (1995) A stakeholder framework for analyzing and evaluating corporate social performance. Acad Manag Rev 20(1):92-117. https://doi.org/10.5465/amr.1995.9503271994

Crane A, Glozer S (2016) Researching corporate social responsibility communication: themes, opportunities and challenges. J Manag Stud 53(7):1223-1252. https://doi.org/10.1111/joms.12196

Crane A, Henriques I, Husted BW, Matten D (2015) A new era for business and society. Bus Soc 54(1):38. https://doi.org/10.1177/0007650314557998

Crane A, Henriques I, Husted BW (2018) Quants and poets: advancing methods and methodologies in business and society research. Bus Soc 57(1):3-25. https://doi.org/10.1177/0007650317718129

Dahlsrud A (2008) How corporate social responsibility is defined: an analysis of 37 definitions. Corp Soc Responsib Environ Manag 15(1):1-13. https://doi.org/10.1002/csr.132

Davis K (1960) Can business afford to ignore social responsibilities? Calif Manag Rev 2(3):70-76. https://doi.org/10.2307/41166246

De Bakker FG, Groenewegen P, den Hond F (2005) A bibliometric analysis of 30 years of research and theory on corporate social responsibility and corporate social performance. Bus Soc 44(3):283317. https://doi.org/10.1177/0007650305278086

De Jong MD, Harkink KM, Barth S (2018) Making green stuff? Effects of corporate greenwashing on consumers. J Bus Tech Commun 32(1):77-112. https://doi.org/10.1177/1050651917729863

De Roeck K, Marique G, Stinglhamber F, Swaen V (2014) Understanding employees' responses to corporate social responsibility: mediating roles of overall justice and organisational identification. Int $\mathbf{J}$ Hum Resour Manag 25(1):91-112. https://doi.org/10.1080/09585192.2013.781528

DiMaggio PJ, Powell WW (1983) The iron case revisited: institutional isomorphism and collective rationality in organizational field. Am Sociol Rev 48(2):147-160. https://doi.org/10.2307/2095101

Doh JP, Guay TR (2006) Corporate social responsibility, public policy, and NGO activism in Europe and the United States: an institutional-stakeholder perspective. J Manag Stud 43(1):47-73. https://doi. org/10.1111/j.1467-6486.2006.00582.x

Donaldson T, Preston LE (1995) The stakeholder theory of the corporation: concepts, evidence, and implications. Acad Manag Rev 20(1):65-91. https://doi.org/10.5465/amr.1995.9503271992

Du S, Bhattacharya CB, Sen S (2010) Maximizing business returns to corporate social responsibility (CSR): the role of CSR communication. Int J Manag Rev 12(1):8-19. https://doi.org/10.1111/j. 1468-2370.2009.00276.x

Dutton JE, Dukerich JM, Harquail CV (1994) Organizational images and member identification. Admin Sci Q 39(2):239-263. https://doi.org/10.2307/2393235

Farooq O, Payaud M, Merunka D, Valette-Florence P (2014) The impact of corporate social responsibility on organizational commitment: exploring multiple mediation mechanisms. J Bus Ethics 125(4):563-580. https://doi.org/10.1007/s10551-013-1928-3

Forehand MR, Grier S (2003) When is honesty the best policy? The effect of stated company intent on consumer skepticism. J Consum Psychol 13(3):349-356. https://doi.org/10.1207/S15327663J CP1303_15

Fornell C, Larcker DF (1981) Evaluating structural equation models with unobservable variables and measurement error. J Mark Res 18(1):39-50. https://doi.org/10.1177/002224378101800104

Freeman LC (1978) Centrality in social networks conceptual clarification. Soc Netw 1(3):215-239. https://doi.org/10.1016/0378-8733(78)90021-7

Freeman RE (1984) Strategic management: a stakeholder approach. Pitman, Boston

Friedman M (1970, September 13) The social responsibility of business is to increase its profits. The New York Times Magazine

Frynas JG, Stephens S (2015) Political corporate social responsibility: reviewing theories and setting new agendas. Int J Manag Rev 17(4):483-509. https://doi.org/10.1111/ijmr.12049

Frynas JG, Yamahaki C (2016) Corporate social responsibility: review and roadmap of theoretical perspectives. Bus Ethics Eur Rev 25(3):258-285. https://doi.org/10.1111/beer.12115

Garriga E, Melé D (2004) Corporate social responsibility theories: mapping the territory. J Bus Ethics 53(1-2):51-71. https://doi.org/10.1023/B:BUSI.0000039399.90587.34

Glavas A, Kelley K (2014) The effects of perceived corporate social responsibility on employee attitudes. Bus Ethics Q 24(2):165-202. https://doi.org/10.5840/beq20143206 
Godfrey PC, Merrill CB, Hansen JM (2009) The relationship between corporate social responsibility and shareholder value: an empirical test of the risk management hypothesis. Strateg Manag $\mathbf{J}$ 30(4):425-445. https://doi.org/10.1002/smj.750

Gond JP, Matten D (2007) Rethinking the business-society interface: beyond the functionalist trap. International centre for corporate social responsibility research paper series no. 47. Nottingham University Business School, Nottingham

Gond JP, El Akremi A, Swaen V, Babu N (2017) The psychological microfoundations of corporate social responsibility: a person-centric systematic review. J Organ Behav 38(2):225-246. https://doi.org/ 10.1002/job. 2170

Gond JP, Mena S, Mosonyi S (2020) The performativity of literature reviewing: constituting the corporate social responsibility literature through re-presentation and intervention. Organ Res Methods. https://doi.org/10.1177/1094428120935494

Greening DW, Turban DB (2000) Corporate social performance as a competitive advantage in attracting a quality workforce. Bus Soc 39(3):254-280. https://doi.org/10.1177/000765030003900302

Greenwood R, Raynard M, Kodeih F, Micelotta ER, Lounsbury M (2011) Institutional complexity and organizational responses. Acad Manag Ann 5(1):317-371. https://doi.org/10.5465/19416520.2011. 590299

Griffin JJ, Mahon JF (1997) The corporate social performance and corporate financial performance debate: twenty-five years of incomparable research. Bus Soc 36(1):5-31. https://doi.org/10.1177/ 000765039703600102

Hart SL (1995) A natural-resource-based view of the firm. Acad Manag Rev 20(4):986-1014. https://doi. org/10.5465/amr.1995.9512280033

Hessari NM, Petticrew M (2018) What does the alcohol industry mean by 'responsible drinking'? A comparative analysis. J Public Health 40(1):90-97. https://doi.org/10.1093/pubmed/fdx040

Hillman AJ, Keim GD (2001) Shareholder value, stakeholder management, and social issues: what's the bottom line? Strateg Manag J 22(2):125-139. https://doi.org/10.1002/1097-0266(200101)22:2< 125::AID-SMJ150>3.0.CO;2-H

Hoffmann J (2018) Talking into (non) existence: denying or constituting paradoxes of corporate social responsibility. Hum Relat 71(5):668-691. https://doi.org/10.1177/0018726717721306

Jammulamadaka N (2020) Reading institutional logics of CSR in India from a post-colonial location. J Bus Ethics 163(3):599-617. https://doi.org/10.1007/s10551-018-4041-9

Jenkins H (2006) Small business champions for corporate social responsibility. J Bus Ethics 67(3):241256. https://doi.org/10.1007/s10551-006-9182-6

Ji YG, Tao W, Rim H (2021) Theoretical insights of CSR research in communication from 1980 to 2018 : a bibliometric network analysis. J Bus Ethics. https://doi.org/10.1007/s10551-021-04748-w

Jones DA (2010) Does serving the community also serve the company? Using organizational identification and social exchange theories to understand employee responses to a volunteerism programme. J Occup Organ Psychol 83(4):857-878. https://doi.org/10.1348/096317909X477495

Jones EE, Davis KE (1965) From acts to dispositions: the attribution process in person perception. In: Berkowitz L (ed) Advances in experimental social psychology, 2nd edn. Academic Press, New York, pp 219-266

Kelley HH (1973) The processes of causal attribution. Am Psychol 28(2):107-128. https://doi.org/10. $1037 / \mathrm{h} 0034225$

Ketprapakorn N (2019) Toward an Asian corporate sustainability model: an integrative review. J Clean Prod 239:117995. https://doi.org/10.1016/j.jclepro.2019.117995

Khan SN (2018) Making sense of the black box: an empirical analysis investigating strategic cognition of CSR strategists in a transitional market. J Clean Prod 196:916-926. https://doi.org/10.1016/j.jclep ro.2018.06.075

Kim HR, Lee M, Lee HT, Kim NM (2010) Corporate social responsibility and employee-company identification. J Bus Ethics 95(4):557-569. https://doi.org/10.1007/s10551-010-0440-2

Klonoski RJ (1991) Foundational considerations in the corporate social responsibility debate. Bus Horizons 34(4):9-18. https://doi.org/10.1016/0007-6813(91)90002-D

Kostova T, Zaheer S (1999) Organizational legitimacy under conditions of complexity: the case of the multinational enterprise. Acad Manag Rev 24(1):64-81. https://doi.org/10.5465/amr.1999.1580441

Kuntner T, Teichert T (2016) The scope of price promotion research: an informetric study. J Bus Res 69(8):2687-2696. https://doi.org/10.1016/j.jbusres.2015.11.004 
Langville AN, Meyer CD (2006) Google's pagerank and beyond. Princeton University Press, Princeton

Lee PKC, Lau AKW, Cheng TCE (2013) Employee rights protection and financial performance. J Bus Res 66(10):1861-1869. https://doi.org/10.1016/j.jbusres.2013.02.007

Lee CJ, Wang R, Lee CY, Hung CC, Hsu SC (2018) Board structure and directors' role in preventing corporate misconduct in the construction industry. J Manag Eng 34(2):04017067. https://doi.org/ 10.1061/(ASCE)ME.1943-5479.0000593

Lichtenstein DR, Drumwright ME, Braig BM (2004) The effect of corporate social responsibility on customer donations to corporate-supported nonprofits. J Mark 68(4):16-32. https://doi.org/10.1509/ jmkg.68.4.16.42726

Lockett A, Moon J, Visser W (2006) Corporate social responsibility in management research: focus, nature, salience and sources of influence. J Manag Stud 43(1):115-136. https://doi.org/10.1111/j. 1467-6486.2006.00585.x

Luo X, Bhattacharya CB (2006) Corporate social responsibility, customer satisfaction, and market value. J Mark 70(4):1-18. https://doi.org/10.1509/jmkg.70.4.001

Lynn A (2021) Why "doing well by doing good" went wrong: getting beyond "good ethics pays" claims in managerial thinking. Acad Manag Rev 46(3):512-533. https://doi.org/10.5465/amr.2018.0250

Ma Z (2009) The status of contemporary business ethics research: present and future. J Bus Ethics 90(3):255-265. https://doi.org/10.1007/s10551-010-0420-6

Ma Z, Liang D, Yu KH, Lee Y (2012) Most cited business ethics publications: mapping the intellectual structure of business ethics studies in 2001-2008. Bus Ethics Eur Rev 21(3):286-297. https://doi. org/10.1111/j.1467-8608.2012.01652.x

Maak T, Pless NM, Voegtlin C (2016) Business statesman or shareholder advocate? CEO responsible leadership styles and the micro-foundations of political CSR. J Manag Stud 53(3):463-493. https:// doi.org/10.1111/joms.12195

Maignan I, Ferrell OC (2004) Corporate social responsibility and marketing: an integrative framework. J Acad Mark Sci 32(1):3-19. https://doi.org/10.1177/0092070303258971

Maignan I, Ferrell OC, Hult GTM (1999) Corporate citizenship: cultural antecedents and business benefits. J Acad Mark Sci 27(4):455-469. https://doi.org/10.1177/0092070399274005

Margolis JD, Walsh JP (2003) Misery loves companies: rethinking social initiatives by business. Admin Sci Q 48(2):268-305. https://doi.org/10.2307/3556659

Matten D, Crane A (2005) Corporate citizenship: toward an extended theoretical conceptualization. Acad Manag Rev 30(1):166-179. https://doi.org/10.5465/amr.2005.15281448

Matten D, Moon J (2008) 'Implicit' and 'explicit' CSR: a conceptual framework for a comparative understanding of corporate social responsibility. Acad Manag Rev 33(2):404-424. https://doi.org/10. 5465/amr.2008.31193458

McWilliams A, Siegel D (2000) Corporate social responsibility and financial performance: correlation or misspecification? Strateg Manag J 21(5):603-609. https://doi.org/10.1002/(SICI)10970266(200005)21:5<603::AID-SMJ101>3.0.CO;2-3

McWilliams A, Siegel D (2001) Corporate social responsibility: a theory of the firm perspective. Acad Manag Rev 26(1):117-127. https://doi.org/10.5465/amr.2001.4011987

McWilliams A, Siegel D, Wright PM (2006) Corporate social responsibility: strategic implications. J Manag Stud 43(1):1-18. https://doi.org/10.1111/j.1467-6486.2006.00580.x

Meyer JW, Rowan B (1977) Institutionalized organizations: formal structure as myth and ceremony. Am J Sociol 83(2):340-363. https://doi.org/10.1086/226550

Mills RA, De Paoli S (2018) When situativity meets objectivity in peer production of knowledge: the case of the WikiRate platform. Data Technol Appl 52(1):16-33. https://doi.org/10.1108/ DTA-02-2017-0006

Mitchell RK, Agle BR, Wood DJ (1997) Toward a theory of stakeholder identification and salience: defining the principle of who and what really counts. Acad Manag Rev 22(4):853-886. https://doi. org/10.5465/amr.1997.9711022105

Mitnick BM (2019) The distinction of fields. Bus Soc 58(7):1309-1333. https://doi.org/10.1177/00076 50317718498

Mitnick BM, Windsor D, Wood DJ (2021) CSR: undertheorized or essentially contested? Acad Manag Rev 46(3):623-629. https://doi.org/10.5465/amr.2020.0239

Mitra R, Buzzanell PM (2017) Communicative tensions of meaningful work: the case of sustainability practitioners. Hum Relat 70(5):594-616. https://doi.org/10.1177/0018726716663288 
Morgan RM, Hunt SD (1994) The commitment-trust theory of relationship marketing. J Mark 58(3):20 38. https://doi.org/10.1177/002224299405800302

Morsing M, Schultz M, Nielsen KU (2008) The 'Catch 22'of communicating CSR: findings from a Danish study. J Mark Commun 14(2):97-111. https://doi.org/10.1080/13527260701856608

Munro V, Arli D, Rundle-Thiele S (2018) CSR engagement and values in a pre-emerging and emerging country context. Int J Emerg Mark 13(5):1251-1272. https://doi.org/10.1108/IJoEM-04-2018-0163

Oliver C (1991) Strategic responses to institutional processes. Acad Manag Rev 16(1):145-179. https:// doi.org/10.5465/amr.1991.4279002

Orlitzky M, Schmidt FL, Rynes SL (2003) Corporate social and financial performance: a meta-analysis. Organ Stud 24(3):403-441. https://doi.org/10.1177/0170840603024003910

Peterson DK (2004) The relationship between perceptions of corporate citizenship and organizational commitment. Bus Soc 43(3):296-319. https://doi.org/10.1177/0007650304268065

Petticrew M, Hessari NM, Knai C, Weiderpass E (2018) How alcohol industry organisations mislead the public about alcohol and cancer. Drug Alcohol Rev 37(3):293-303. https://doi.org/10.1111/dar. 12596

Pfeffer J, Salancik GR (1978) The external control of organizations: a resource dependence perspective. Harper \& Row, New York

Pilkington A, Teichert T (2006) Management of technology: themes, concepts and relationships. Technovation 26(3):288-299. https://doi.org/10.1016/j.technovation.2005.01.009

Podsakoff PM, MacKenzie SB, Lee JY, Podsakoff NP (2003) Common method biases in behavioral research: a critical review of the literature and recommended remedies. J Appl Psychol 88(5):879903. https://doi.org/10.1037/0021-9010.88.5.879

Porter ME, Kramer MR (2006) Strategy \& society: the link between competitive advantage and corporate social responsibility. Harvard Bus Rev 84(12):78-92

Rupp DE, Mallory DB (2015) Corporate social responsibility: psychological, person-centric, and progressing. Annu Rev Organ Psychol Organ Behav 2(1):211-236. https://doi.org/10.1146/annurevorgpsych-032414-111505

Rupp DE, Ganapathi J, Aguilera RV, Williams CA (2006) Employee reactions to corporate social responsibility: an organizational justice framework. J Organ Behav 27(4):537-543. https://doi.org/10. 1002/job.380

Rupp DE, Shao R, Thornton MA, Skarlicki DP (2013) Applicants' and employees' reactions to corporate social responsibility: the moderating effects of first-party justice perceptions and moral identity. Pers Psychol 66(4):895-933. https://doi.org/10.1111/peps.12030

Russo MV, Fouts PA (1997) A resource-based perspective on corporate environmental performance and profitability. Acad Manag J 40(3):534-559. https://doi.org/10.5465/257052

Scherer AG, Palazzo G (2007) Toward a political conception of corporate responsibility: business and society seen from a Habermasian perspective. Acad Manag Rev 32(4):1096-1120. https://doi.org/ 10.5465/amr.2007.26585837

Scherer AG, Palazzo G (2011) The new political role of business in a globalized world: a review of a new perspective on CSR and its implications for the firm, governance, and democracy. J Manag Stud 48(4):899-931. https://doi.org/10.1111/j.1467-6486.2010.00950.x

Scott WR (1995) Institutions and organizations. Sage Publications, Thousand Oaks

Secchi D (2007) Utilitarian, managerial and relational theories of corporate social responsibility. Int J Manag Rev 9(4):347-373. https://doi.org/10.1111/j.1468-2370.2007.00215.x

Sen S, Bhattacharya CB (2001) Does doing good always lead to doing better? Consumer reactions to corporate social responsibility. J Mark Res 38(2):225-243. https://doi.org/10.1509/jmkr.38.2.225. 18838

Sen S, Bhattacharya CB, Korschun D (2006) The role of corporate social responsibility in strengthening multiple stakeholder relationships: a field experiment. J Acad Mark Sci 34(2):158-166. https://doi. org/10.1177/0092070305284978

Sharma S, Vredenburg H (1998) Proactive corporate environmental strategy and the development of competitively valuable organizational capabilities. Strat Manag J 19(8):729-753. https://doi.org/10. 1002/(SICI)1097-0266(199808)19:8<729::AID-SMJ967>3.0.CO;2-4

Shirodkar V, Beddewela E, Richter UH (2018) Firm-level determinants of political CSR in emerging economies: evidence from India. J Bus Ethics 148(3):673-688. https://doi.org/10.1007/ s10551-016-3022-0 
Skarmeas D, Leonidou CN (2013) When consumers doubt, watch out! The role of CSR skepticism. J Bus Res 66(10):1831-1838. https://doi.org/10.1016/j.jbusres.2013.02.004

Small HG (1977) A co-citation model of a scientific specialty: a longitudinal study of collagen research. Soc Stud Sci 7(2):139-166. https://doi.org/10.1177/030631277700700202

Suchman MC (1995) Managing legitimacy: strategic and institutional approaches. Acad Manag Rev 20(3):571-610. https://doi.org/10.5465/amr.1995.9508080331

Surroca J, Tribó JA, Waddock S (2010) Corporate responsibility and financial performance: the role of intangible resources. Strateg Manag J 31(5):463-490. https://doi.org/10.1002/smj.820

Teichert T, Shehu E (2010) Investigating research streams of conjoint analysis: a bibliometric study. Bus Res 3(1):49-68. https://doi.org/10.1007/BF03342715

Trethewey GEA, Ashcraft KL (2004) Practicing disorganization: the development of applied perspectives on living with tension. J Appl Commun Res 32(2):81-88. https://doi.org/10.1080/0090988042 000210007

Turban DB, Greening DW (1997) Corporate social performance and organizational attractiveness to prospective employees. Acad Manag J 40(3):658-672. https://doi.org/10.5465/257057

Turker D (2009a) Measuring corporate social responsibility: a scale development study. J Bus Ethics 85(4):411-427. https://doi.org/10.1007/s10551-008-9780-6

Turker D (2009b) How corporate social responsibility influences organizational commitment. J Bus Ethics 89(2):189-204. https://doi.org/10.1007/s10551-008-9993-8

Van Marrewijk M (2003) Concepts and definitions of CSR and corporate sustainability: between agency and communion. J Bus Ethics 44(2):95-105. https://doi.org/10.1023/A:1023331212247

Verk N, Golob U, Podnar K (2021) A dynamic review of the emergence of corporate social responsibility communication. J Bus Ethics 168(3):491-515. https://doi.org/10.1007/s10551-019-04232-6

Vlachos PA, Tsamakos A, Vrechopoulos AP, Avramidis PK (2009) Corporate social responsibility: attributions, loyalty, and the mediating role of trust. J Acad Mark Sci 37(2):170-180. https://doi.org/10. 1007/s11747-008-0117-x

Vlachos PA, Panagopoulos NG, Rapp AA (2014) Employee judgments of and behaviors toward corporate social responsibility: a multi-study investigation of direct, cascading, and moderating effects. J Organ Behav 35(7):990-1017. https://doi.org/10.1002/job.1946

Waddock SA, Graves SB (1997) The corporate social performance-financial performance link. Strateg Manag J 18(4):303-319. https://doi.org/10.1002/(SICI)1097-0266(199704)18:4<303::AID-SMJ86 9>3.0.CO;2-G

Wang H, Tong L, Takeuchi R, George G (2016) Corporate social responsibility: an overview and new research directions: thematic issue on corporate social responsibility. Acad Manag J 59(2):534544. https://doi.org/10.5465/amj.2016.5001

Weick KE, Sutcliffe KM, Obstfeld D (2005) Organizing and the process of sensemaking. Organ Sci 16(4):409-421. https://doi.org/10.1287/orsc.1050.0133

Wernerfelt B (1984) A resource-based view of the firm. Strateg Manag J 5(2):171-180. https://doi.org/10. 1002/smj.4250050207

White HD, Griffith BC (1981) Author cocitation: a literature measure of intellectual structure. J Am Soc Inf Sci 32(3):163-171. https://doi.org/10.1002/asi.4630320302

Whittington R (1996) Strategy as practice. Long Range Plan 29(5):731-735. https://doi.org/10.1016/ 0024-6301(96)00068-4

Wickert C (2016) "Political" corporate social responsibility in small-and medium-sized enterprises: a conceptual framework. Bus Soc 55(6):792-824. https://doi.org/10.1177/0007650314537021

Windsor D (2006) Corporate social responsibility: three key approaches. J Manag Stud 43(1):93-114. https://doi.org/10.1111/j.1467-6486.2006.00584.x

Wood DJ (1991) Corporate social performance revisited. Acad Manag Rev 16(4):691-718. https://doi. org/10.2307/258977

Wood DJ, Logsdon JM (2019) Social issues in management as a distinct field: corporate social responsibility and performance. Bus Soc 58(7):1334-1357. https://doi.org/10.1177/0007650316680041

Wörfel P (2019) Unravelling the intellectual discourse of implicit consumer cognition: a bibliometric review. J Retail Consum Serv 61:101960. https://doi.org/10.1016/j.jretconser.2019.101960

Yoon Y, Gürhan-Canli Z, Schwarz N (2006) The effect of corporate social responsibility (CSR) activities on companies with bad reputations. J Consum Psychol 16(4):377-390. https://doi.org/10.1207/ s15327663jcp1604_9 
Zhao Z, Meng F, He Y, Gu Z (2019) The influence of corporate social responsibility on competitive advantage with multiple mediations from social capital and dynamic capabilities. Sustainability 11(1):218. https://doi.org/10.3390/su11010218

Zupic I, Čater T (2015) Bibliometric methods in management and organization. Organ Res Methods 18(3):429-472. https://doi.org/10.1177/1094428114562629

Publisher's Note Springer Nature remains neutral with regard to jurisdictional claims in published maps and institutional affiliations. 